\title{
Microtremor measurements in the northern coast of İzmir Bay, Turkey to evaluate site-specific characteristics and fundamental periods by $H / V$ spectral ratio method
}

\author{
TuĞba Eskişar ${ }^{1, *}$, Şenol Özyalin ${ }^{2}$, Mehmet KuruoĞLu ${ }^{3}$ and H Recep Yilmaz ${ }^{1}$ \\ ${ }^{1}$ Ege University, Department of Civil Engineering, Geotechnics Division, 35100 Bornova, Izmir, Turkey. \\ ${ }^{2}$ Dokuz Eylül University, Department of Geophysics, 35160 Buca, Izmir, Turkey. \\ ${ }^{3}$ Dokuz Eylül University, Department of Civil Engineering, Geotechnics Division, 35160, Buca, Izmir, Turkey. \\ *Corresponding author. e-mail: tugba.eskisar@ege.edu.tr
}

Seventy-two microtremor measurements were conducted in the northern coast of İzmir Bay. The dataset has been processed using the horizontal-to-vertical spectral ratio. The fundamental period contour map obtained showed that the fundamental period at rock sites of the northern coast of İmir Bay was between 0.15 and $0.35 \mathrm{~s}$. However, the fundamental period increased towards the western direction where thick soft sediments exist, the fundamental period varied between 0.5 and $2.0 \mathrm{~s}$. A soil classification map of the area was prepared based on the data estimated from SPT- $N$ values of 25 boreholes. It is seen that major portion of the study area, including the shore line of the northern coast had SPT- $N$ values lower than 15 . The fundamental periods obtained by $H / V$ spectral ratio method and the periods derived from shear wave velocity data available in 11 of 25 boreholes were well-correlated. Fundamental period map obtained from $H / V$ spectral ratio method illustrated the characteristics of weak soil conditions and the presence of bedrock level under thick alluvial soils. Finally, microtremor investigations have proved to be an effective tool for assessment of local soil conditions in case of thick soft sediments in the northern coast of İzmir Bay.

\section{Introduction}

The city of İzmir and its neighbourhood have been subjected to destructive earthquakes from historical ages to recent times due to the tectonic activity in Western Anatolia: 1974 İzmir Earthquake, $M_{w}=5.5 ; 1977$ İzmir Earthquake, $M_{w}=5.3 ; 1992$ Doğanbey Earthquake, $M_{w}=6.0 ; 2003$ Urla Earthquake, $M_{w}=5.6 ; 2005$ Uzunkuyu-Urla Earthquake, $M_{w}=5.9$ were moderate scale earthquakes $(M>5)$ that struck the city in instrumental period (DEMP-ED 2012).
In the last decades, population of the city increased rapidly in the northern part of the city and this trend is still expected for the following decades. Besides, a new metropolitan area is developing with ongoing urban development plan in the northern coast of İzmir. İzmir Atatürk Organized Industrial Zone (IAOIZ) which constitutes the backbone of Izmir's economy is located at the western end of the area. For these reasons, the present study is performed in the northern part of Izmir. The northern coast of İzmir is considered as a marginal land due to the existence of

Keywords. Microtremor; $H / V$ spectral ratio; fundamental period; shear wave velocity; standard penetration test (SPT). 
thick, saturated alluvial sediments which underlie Mavişehir, Bostanlı and Karşıyaka districts in front of the Yamanlar mountain basements (figure 1). Shear wave velocity measurements performed in the upper $30 \mathrm{~m}$ of the area showed that shear wave velocity is between 100 and $350 \mathrm{~m} / \mathrm{s}$, indicating loose and soft soil characteristics (RADIUS 1999).

During the last 20-30 years, the use of microtremors to assess site effects and produce maps for engineering purposes became very popular throughout the world (Lermo and Chávez-García 1993, 1994; Nguyen et al. 2004; Gosar 2007; Bonnefoy-Claudet et al. 2008; Walling et al. 2009; Beroya et al. 2009; Manakou et al. 2010; RosaCintas et al. 2011; Sgarlato et al. 2011) as microtremor measurements are convenient, easy and inexpensive both in terms of field operations and data analysis.
The single station method is the most practical and feasible alternative among the other methods (Mahajan et al. 2011a). This method is simply based on calculation of the ratio of horizontal to vertical microtremor spectra to estimate the $H / V$ spectral ratio and predominant period (Nakamura 1989). The sufficiency of $H / V$ spectral ratio method to provide information related to site response has been proved by different authors (Nakamura 1989; Chávez-García and Cuenca 1996; TevesCosta et al. 1996; Bour et al. 1998; Jensen 2000; Chávez-García and Tejeda-Jácome 2010).

In this study, $H / V$ spectral ratio method has been applied as a reliable tool for estimating the fundamental period, because finding a convenient reference point on a rock site was difficult in the delta, as it was mainly composed of deep alluvial soils. It is realized that the presence of sharp lithological boundaries between the bedrock

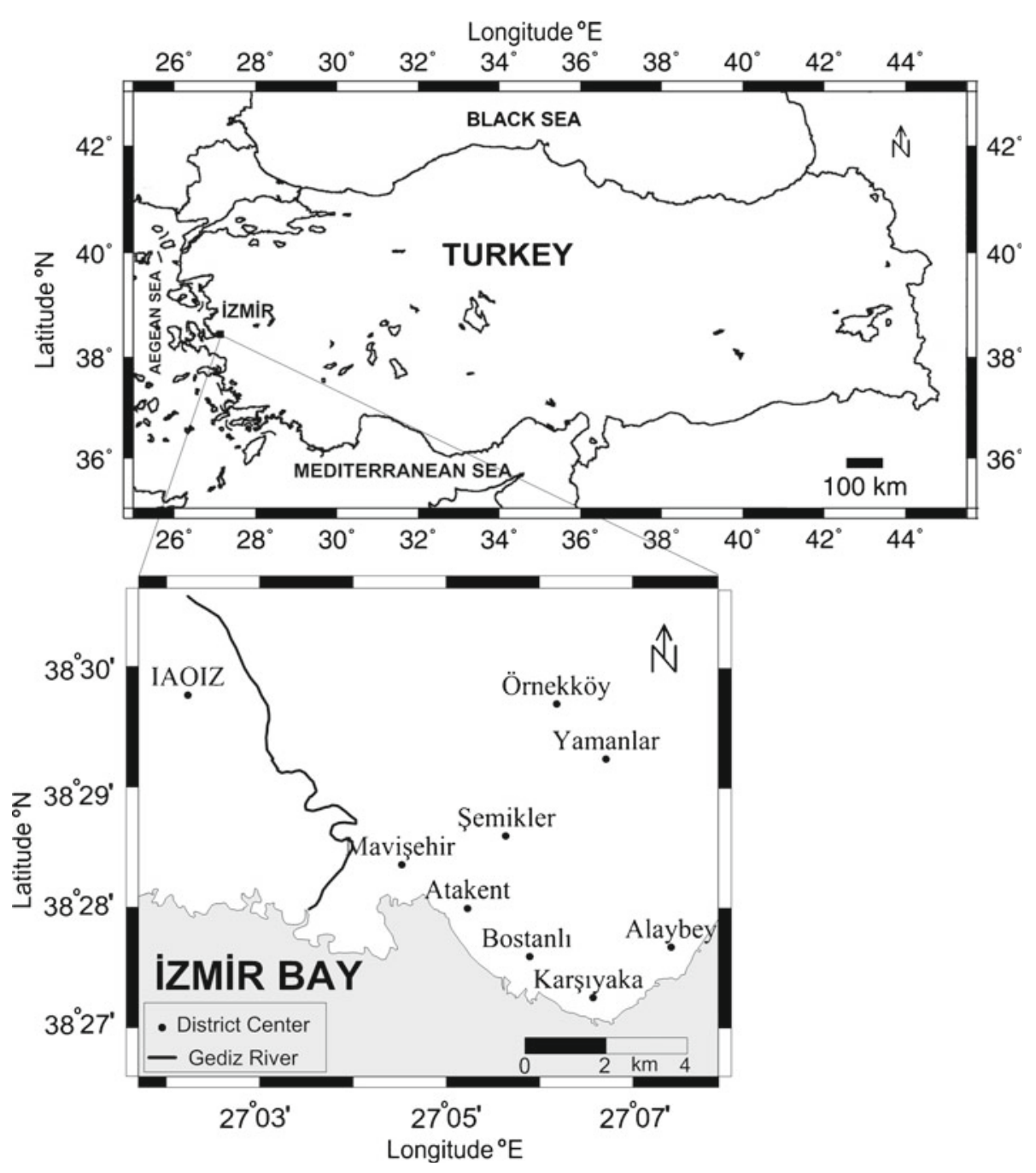

Figure 1. Map of Turkey denoting İzmir city and location map of the study area in İzmir. 
and the overlying thick sediments result in strong impedance contrasts that could affect the local site responses.

Previous studies were performed in the area concerning the geotechnical soil properties and geological information (Kuruoğlu 2004; Eskişar 2008). The former study is focused mainly on Mavişehir district, while the latter investigated the northern coast area in general. These two studies could be regarded as the preliminary works concerning the soils of the northern coast of İzmir Bay. The microtremor measurements given in this paper are a part of the second study.

The local site effects of the northern coast of İzmir Bay area is evaluated by conducting 72 microtremor measurements. As observed, thick sedimentary cover generates amplitude spectra with peaks at periods higher than $1.0 \mathrm{~s}$, and thin sediments generate peaks at periods lower than $0.5 \mathrm{~s}$. The estimated periods and their corresponding amplifications are compared with the surface geology.

\section{Tectonic and geological setting of the study area}

Turkey is one of the most rapidly moving and seismically active parts of the Alpine-Himalayan Mountain Belt (figure 2). The westward motion of Turkey relative to Eurasia is said to be related to the collision of Arabia and Eurasia in the Caucasus and eastern Turkey in the mid-Miocene age generating a thickened crust in the eastern
Turkey (Taymaz 1997). The Aegean region has different geological systems such as Gediz-Küçük Menderes-Büyük Menderes-Alaşehir grabens, and Selendi-Demirci-Gördes basins (figure 3). The Gediz Graben system is assumed to be one of the most seismically active parts of the Aegean Plate (Akinc1 et al. 2000). Furthermore, the region is encircled with various important active normal faults, following a nearly east-west strike. The NESW and NW-SE trending master faults affect the tectonic regime of the region. They have different kinematic characteristics, making this region rapidly change its tectonic pattern (Erdik et al. 1999; Emre and Barka 2000; Bozkurt and Sözbilir 2004).

The study area covers nearly $48 \mathrm{~km}^{2}$, and the lithostragraphic sequence consists of two main units (figure 4). These are Miocene volcanic rocks and Quaternary sediments (Erdoğan 1990). The Upper Miocene volcanic rocks which lie on top of the Neogene-aged sedimentary rocks were formed by several calc-alkaline volcanic activities in this region. The volcanic rocks consist of lithic tuffs, agglomerates and andesites. The order of these volcanic rocks may change locally and andesite may lie on top of the Neogene terrestrial units directly (Koca and Kincal 2004). On the other hand, Quaternary unit consists of slope wash and alluvium covering other units unconformably. Alluvial soils are alluvial fan deposits with deltaic features. These sediments are mainly water-saturated (Eskişar 2008).

Quaternary sediments are predicted to have a maximum thickness of $200-250 \mathrm{~m}$ on the foot wall

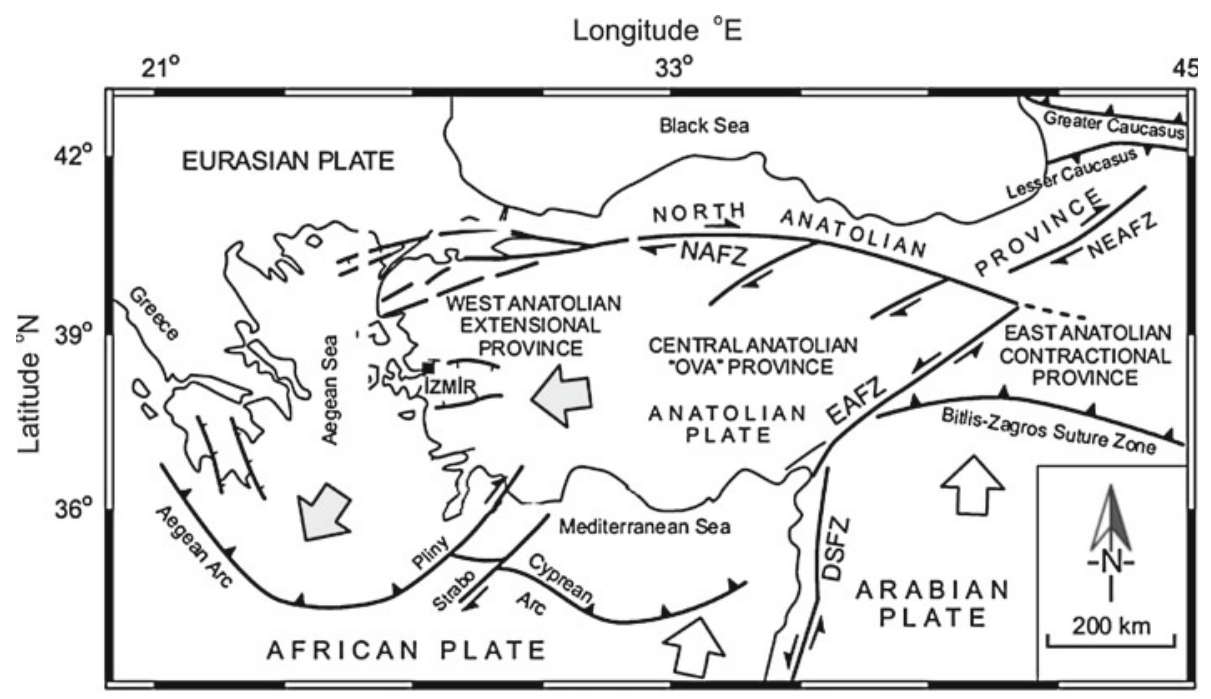

Figure 2. Simplified tectonic map of Turkey showing major neotectonic structures and neotectonic provinces. DSFZ - Dead Sea Fault Zone, EAFZ - East Anatolian Fault Zone, NAFZ - North Anatolian Fault Zone, NEAFZ - Northeast Anatolian Fault Zone. Heavy lines with half arrows are strike-slip faults with arrows showing relative movement sense. Heavy lines with filled triangles show major fold and thrust belt: small triangles indicate direction of vergence. Heavy lines with hachures show normal faults: hachures indicate down-thrown side. Open arrows indicate relative movement direction of African and Arabian plates; bold filled arrows, relative motion of Anatolian Plate (modified from Bozkurt 2001). 


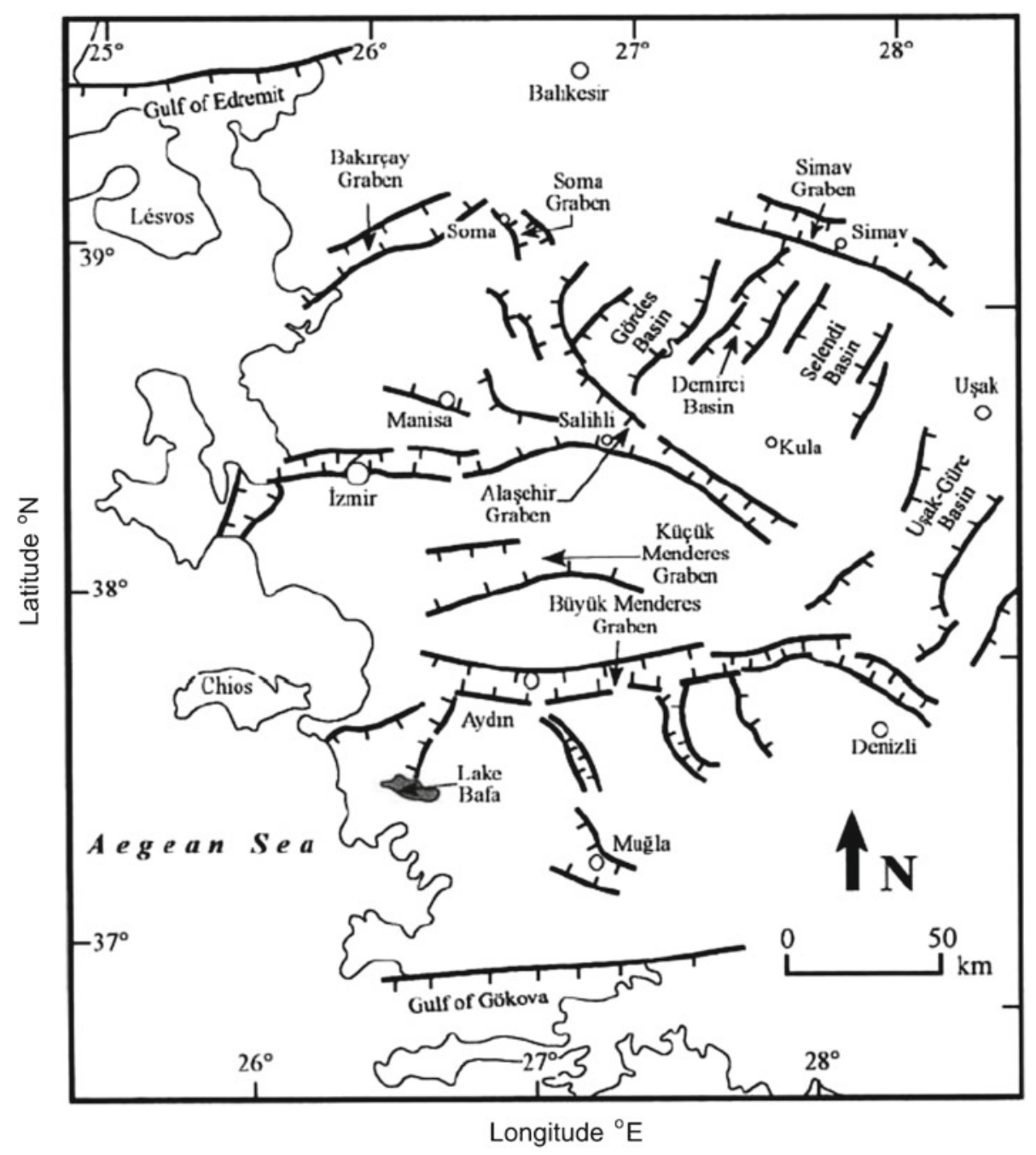

Figure 3. Simplified map showing major structural elements of Western Anatolia. Heavy lines with hachures show normal fault: hachures indicate down-thrown side (Bozkurt 2001; Emre et al. 2005).

block of the Çiğli Fault. In addition, many embedded normal faults covered with the alluvial soils may be placed between Çiğli Fault and the northern coast of Izmir Bay. These normal faults may form a stepped morphology towards the coast from the Çiğli Fault. The area covering Chiğli Fault and the coast have nearly flat topography. The ground water table in the delta varies between 0.5 and $5 \mathrm{~m}$ (Eskişar 2008).

\section{Microtremor data acquisition and methodology}

Microtemor measurements were carried out in 72 locations in the northern part of the city during the period May-July 2008 (figure 5 and table 1). Noise measurements were recorded using a strong motion accelerometer Guralp CMG-5T. This data acquisition system comprises fully integrated triaxial high-sensitive sensors and includes a 24-bit
A/D converter, which has been proved to be very stable with a very low electronic noise level. The standard frequency pass band is flat to acceleration from DC to $100 \mathrm{~Hz}$. A single seismic station was used during the microtremor measurements. Two horizontal and a vertical components of microtremors at each location are recorded for a duration of 30 minutes with 100 samples per second. The trigger threshold was kept at $0.001 \mathrm{~g}$ in the present study for recording microtremor data. A separate global positioning system is used to locate the measurement points.

To prevent man-made noise in the measurements due to industrial and traffic activities, the measurements are taken from late night hours to early morning hours. Especially in the district centres, there are some streets with heavy traffic throughout the day and some are under construction with heavy-duty machines. For this reason, the recordings are not carried out in regular grids. Noise measurements are performed mostly in the Old 


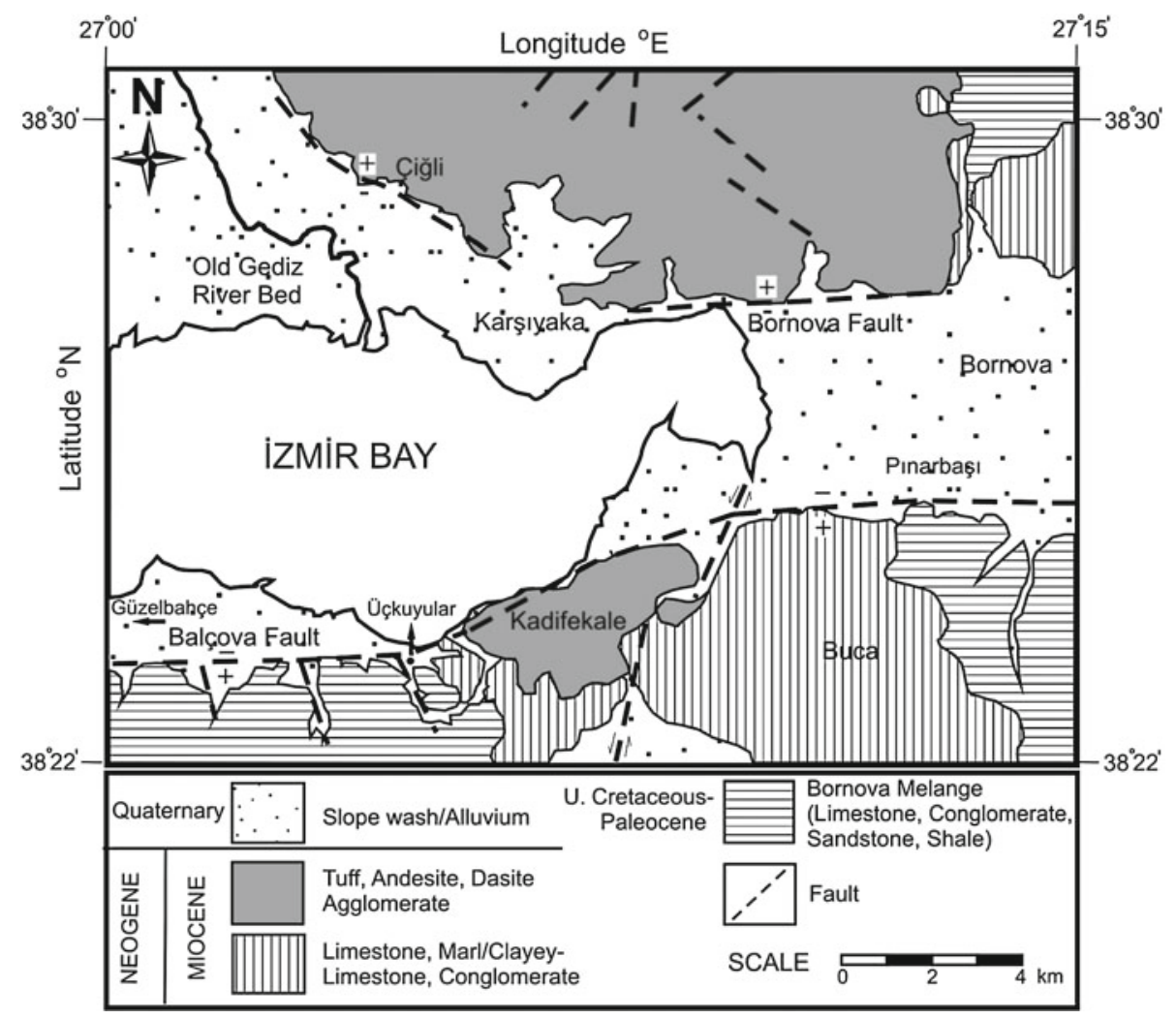

Figure 4. Geological map of the İzmir Metropolitan Area (modified from Tarcan and Koca 2001).

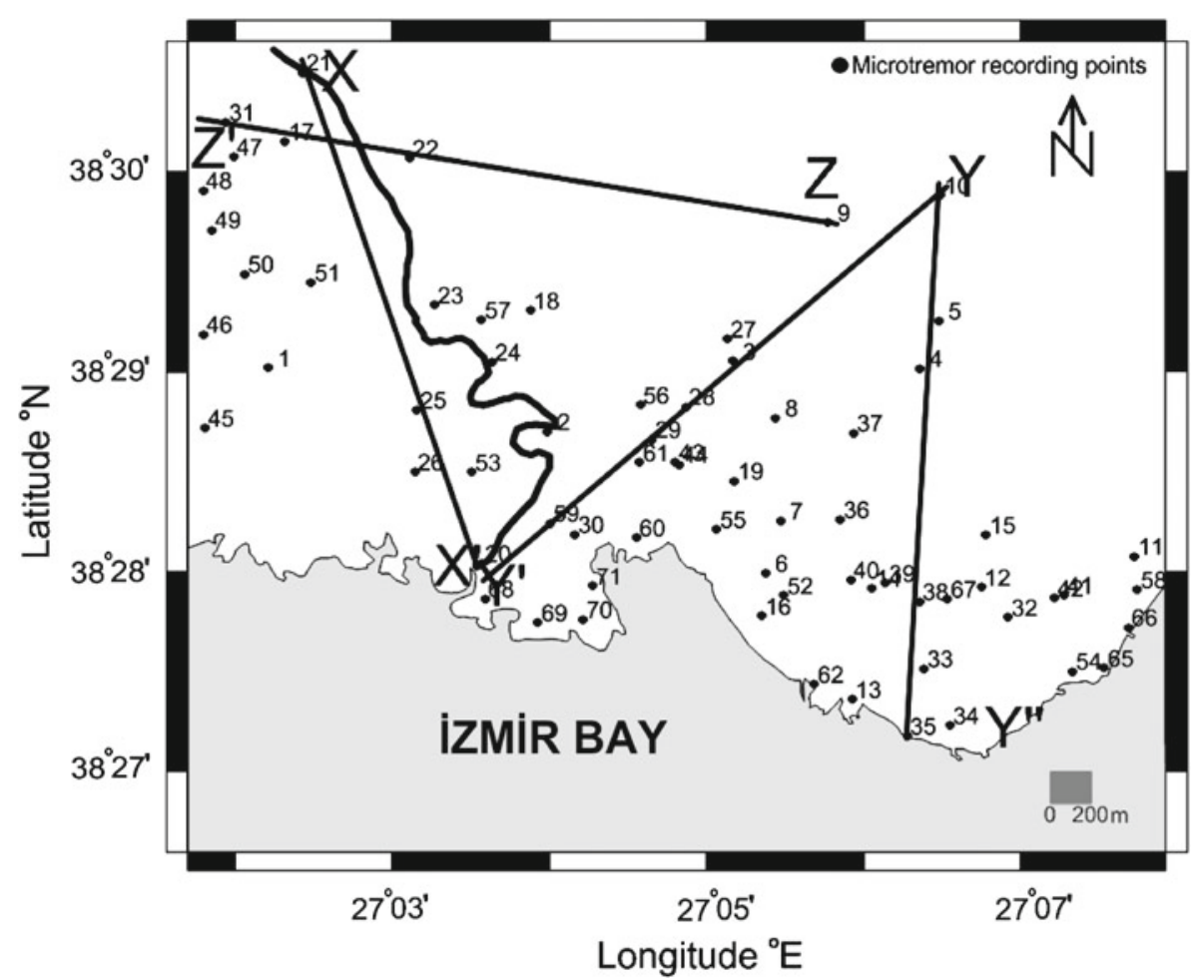

Figure 5. Distribution of microtremor recording points and four cross-sections $\left(X-X^{\prime}, Y-Y^{\prime}, Y-Y^{\prime \prime}\right.$ and $\left.Z-Z^{\prime}\right)$ that cut across the study area. 
Table 1. Fundamental periods measured in the northern coast of İmir Bay.

\begin{tabular}{|c|c|c|c|}
\hline $\begin{array}{l}\text { Station } \\
\text { no. }\end{array}$ & $\begin{array}{l}X \text { coordinate } \\
(\mathrm{m})\end{array}$ & $\begin{array}{c}Y \text { coordinate } \\
(\mathrm{m})\end{array}$ & $\begin{array}{l}\text { Period } \\
\quad(\mathrm{s})\end{array}$ \\
\hline 1 & 503242.30 & 4259476.82 & 1.20 \\
\hline 2 & 505813.31 & 4258889.97 & 0.99 \\
\hline 3 & 507520.78 & 4259539.28 & 0.80 \\
\hline 4 & 509242.34 & 4259471.99 & 0.45 \\
\hline 5 & 509412.87 & 4259914.46 & 0.17 \\
\hline 6 & 507816.52 & 4257576.92 & 1.28 \\
\hline 7 & 507954.70 & 4258062.07 & 0.73 \\
\hline 8 & 507910.45 & 4259015.31 & 0.79 \\
\hline 9 & 508391.73 & 4260823.20 & 0.24 \\
\hline 10 & 509433.00 & 4261077.00 & 0.34 \\
\hline 11 & 511218.83 & 4257736.44 & 0.26 \\
\hline 12 & 509805.28 & 4257448.84 & 0.69 \\
\hline 13 & 508619.61 & 4256412.51 & 0.98 \\
\hline 14 & 508801.04 & 4257442.46 & 0.95 \\
\hline 15 & 509851.15 & 4257934.51 & 0.43 \\
\hline 16 & 507785.61 & 4257182.91 & 1.20 \\
\hline 17 & 503399.01 & 4261573.34 & 1.02 \\
\hline 18 & 505654.82 & 4260009.23 & 1.20 \\
\hline 19 & 507534.75 & 4258433.90 & 0.67 \\
\hline 20 & 505207.81 & 4257668.76 & 2.00 \\
\hline 21 & 503559.17 & 4262211.39 & 0.87 \\
\hline 22 & 504540.02 & 4261417.57 & 0.91 \\
\hline 23 & 504771.34 & 4260059.28 & 0.84 \\
\hline 24 & 505300.22 & 4259532.12 & 1.02 \\
\hline 25 & 504612.29 & 4259087.81 & 1.11 \\
\hline 26 & 504589.85 & 4258515.12 & 1.02 \\
\hline 27 & 507466.10 & 4259746.29 & 0.14 \\
\hline 28 & 507085.88 & 4259119.57 & 0.87 \\
\hline 29 & 506773.53 & 4258815.38 & 1.24 \\
\hline 30 & 506067.03 & 4257939.71 & 1.46 \\
\hline 31 & 502851.69 & 4261750.49 & 1.64 \\
\hline 32 & 510054.71 & 4257169.51 & 1.02 \\
\hline 33 & 509278.98 & 4256696.65 & 1.08 \\
\hline 34 & 509516.51 & 4256173.46 & 1.05 \\
\hline 35 & 509120.92 & 4256073.87 & 1.17 \\
\hline 36 & 508507.39 & 4258076.83 & 0.91 \\
\hline
\end{tabular}

Gediz River Delta alluvial basin, but there are some recordings of Yamanlar mountain basements (figure 1) to check the fundamental period variation. By this means, the applicability of $H / V$ spectral ratio method on the studied region has been investigated. Measurements were performed only on windless days.

For each measurement point, each component of the microtremor data was processed according to the steps proposed by Magri et al. (1994) and Mucciarelli (1998). The mean of the entire signal was removed from each sample (offset correction). Band pass filtering was applied to data with zerophase 2-pole Butterworth filter with nominal corner frequencies of 0.1 and 20 Hertz. At least 10
Table 1. (Continued)

\begin{tabular}{lccc}
\hline Station & $\begin{array}{c}\text { coordinate } \\
\text { no. }\end{array}$ & $\begin{array}{c}Y \text { coordinate } \\
(\mathrm{m})\end{array}$ & $\begin{array}{c}\text { Period } \\
(\mathrm{s})\end{array}$ \\
\hline 37 & 508630.03 & 4258876.36 & 0.12 \\
38 & 509236.29 & 4257319.98 & 1.41 \\
39 & 508928.12 & 4257486.87 & 1.58 \\
40 & 508600.54 & 4257519.48 & 1.78 \\
41 & 510565.23 & 4257376.64 & 1.41 \\
42 & 510478.29 & 4257348.69 & 1.41 \\
43 & 506992.82 & 4258605.62 & 1.02 \\
44 & 507026.33 & 4258587.23 & 1.17 \\
45 & 502658.11 & 4258922.59 & 1.11 \\
46 & 502643.13 & 4259790.23 & 0.91 \\
47 & 502921.98 & 4261430.75 & 0.77 \\
48 & 502640.83 & 4261120.79 & 1.24 \\
49 & 502721.49 & 4260754.37 & 1.20 \\
50 & 503024.53 & 4260346.19 & 1.20 \\
51 & 503639.25 & 4260266.97 & 0.93 \\
52 & 507988.85 & 4257373.54 & 1.24 \\
53 & 505115.40 & 4258513.33 & 1.14 \\
54 & 510645.49 & 4256675.13 & 2.00 \\
55 & 507370.80 & 4257982.36 & 0.73 \\
56 & 506664.50 & 4259134.19 & 0.91 \\
57 & 505206.89 & 4259922.16 & 0.74 \\
58 & 511244.01 & 4257427.49 & 0.95 \\
59 & 505837.88 & 4258042.63 & 1.28 \\
60 & 506630.05 & 4257907.53 & 1.28 \\
61 & 506663.37 & 4258601.46 & 1.11 \\
62 & 508269.12 & 4256551.69 & 1.58 \\
63 & 509601.70 & 4255918.60 & 1.08 \\
64 & 509884.00 & 4255970.17 & 1.52 \\
65 & 510938.88 & 4256701.86 & 1.46 \\
66 & 511158.39 & 4257076.32 & 1.08 \\
67 & 509495.77 & 4257341.81 & 0.72 \\
70 & 505237.43 & 4257342.91 & 2.00 \\
& 505726.21 & 4257120.74 & 2.00 \\
& 506140.93 & 4257150.36 & 2.00 \\
72 & 406229.80 & 4257461.40 & 2.00 \\
& 509799.37 & 4255921.00 & 1.50 \\
\hline 5 & & &
\end{tabular}

windows were selected that did not include transients for stationary and each window had 4096 points. A cosine tapering with a length of $5 \%$ is applied on both sides of the window signal of three components. Fast Fourier Transform (FFT) was applied to each window. The Fourier spectra were smoothed using $0.4 \mathrm{~Hz}$ Parzen's window. The horizontal components were geometrically averaged to generate a single horizontal spectrum. The spectral ratio is averaged over all windows results. An example of the data processing is shown in figure $6(\mathrm{a}, \mathrm{b})$.

Type of instrument used to record the ambient noise is important to evaluate the site effects. It is generally accepted that seismometers are more reliable than accelerometers to record ambient 

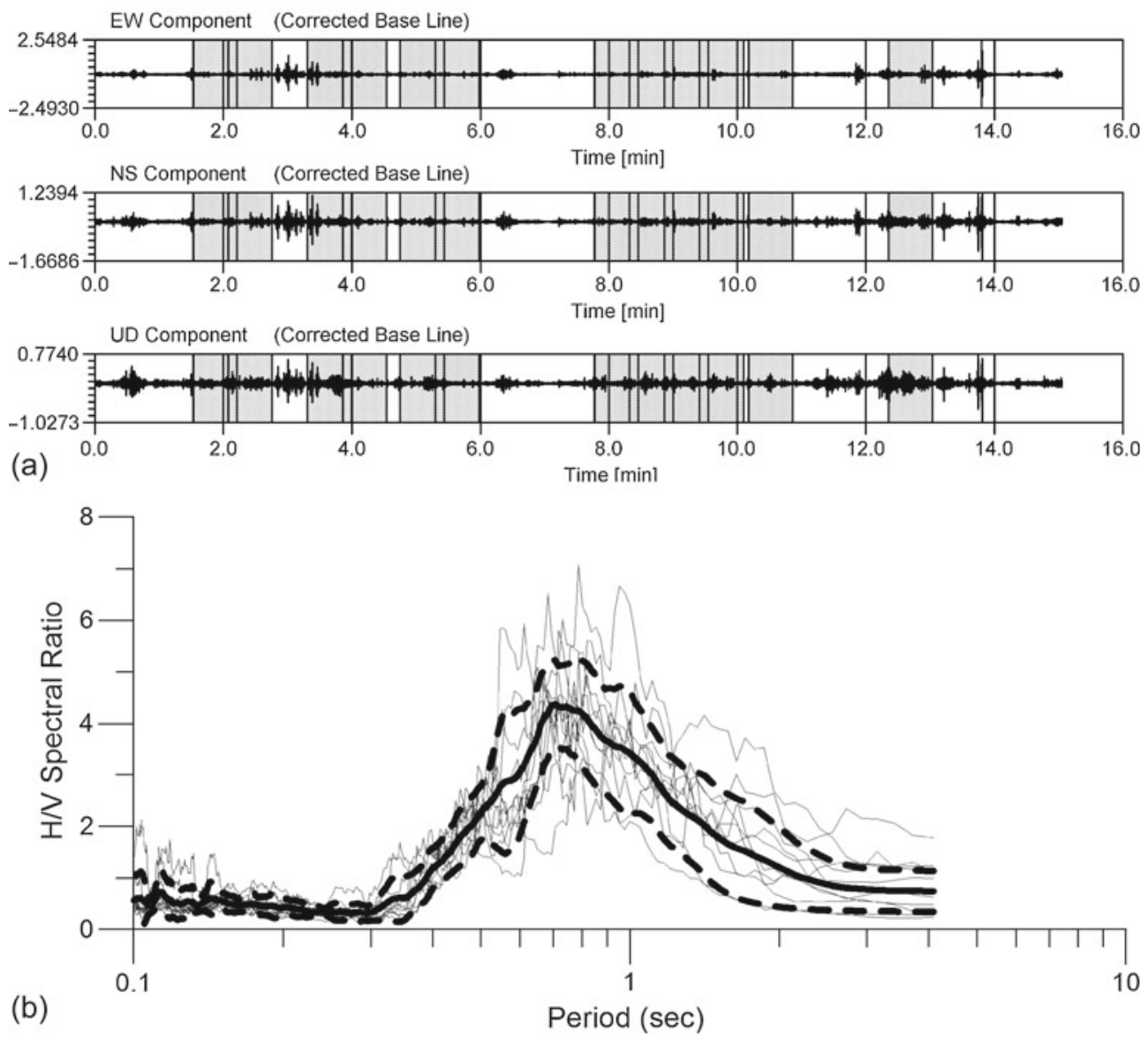

Figure 6. (a) An example of time-series acquired by direct microtremor measurement in the field. (b) Measured $H / V$ spectral ratios, their mean $H / V$ spectral ratios, and \pm standard deviation computed for the same example point.

vibration. However, good matching results have been reported using ambient vibration recorded with accelerometers in recent studies (Mukhopadhyay and Bormann 2004; Hasancebi and Ulusay 2006; Nunziata 2007; Gamal 2009; Chávez-García and Tejeda-Jácome 2010). Due to non-availability of a seismometer, the measurements were performed with an accelerometer during this study. Recently, the accuracy of the results obtained by CMG-5T sensor was cross-checked simultaneously by using a Guralp CMG 6-TD seismometer at two test sites inside the study area. The resonance frequencies obtained from both instruments match well with each other and $H / V$ spectral ratio curves are shown in figure $7(\mathrm{a}, \mathrm{b})$. These points are close to the locations of points 5 and 3 , respectively (figures 5 and 8).

\section{Results and discussion}

$H / V$ spectral ratio method is applied to 72 microtremor measurements to provide information related to site response of the northern coast of İzmir Bay soils. Measurements can be categorized into two classes: (a) points close to the hard rock exposure and (b) points over the alluvial sediments. The $H / V$ spectral ratio over the hard rock shows a response with smaller peaks at lower periods while the measurement points over the deep sedimentary soils show sharper peaks at higher periods. The presence of a clear peak on $H / V$ spectral ratio curve is considered as a distinct impedance contrast between the upper homogeneous soft or loose soil layers and the underlying bedrock. Random measurement points are selected to show $H / V$ spectral ratio curves of the area (figure 8). Figure 9 represents five locations from west to east and figure 10 represents five locations from south to north, respectively. The results obtained by microtremor studies show reliable results when the geological and geotechnical characteristics of the site are considered. Figures 9 and 10 show the moderate progress of resonance periods in $\mathrm{E}-\mathrm{W}$ and $\mathrm{N}-$ $\mathrm{S}$ directions. The main feature on figure 9 is that a systematic decrease of the fundamental period is observed from west to east, from $0.9 \mathrm{~s}$ in the western part to about $0.15 \mathrm{~s}$ in the east, in accordance with the thickness variation of the Quaternary sedimentary deposits. In figure 10, there is also a 

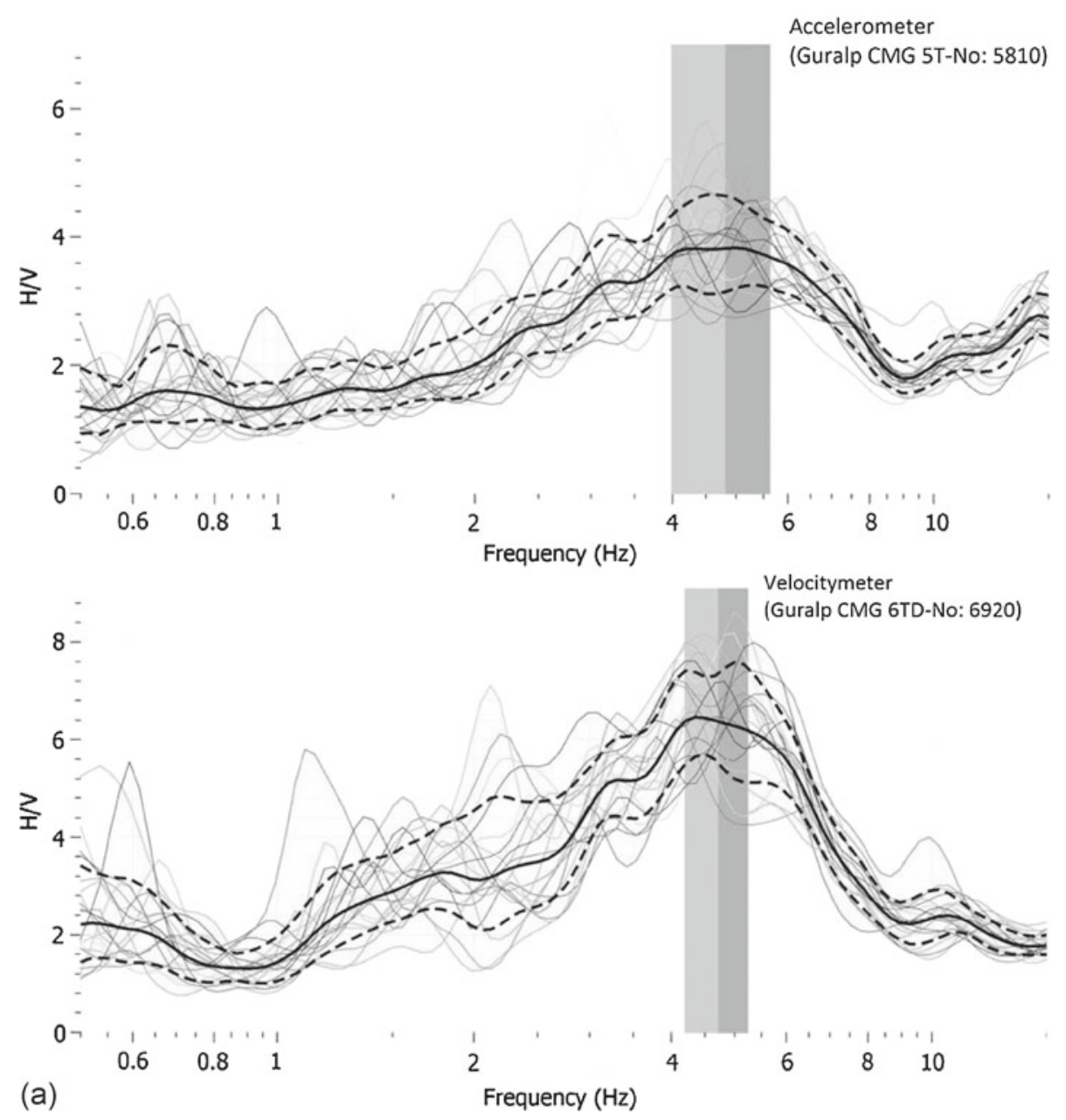

Figure 7. Comparison of fundamental frequencies derived by CMG 5T accelerometer and CMG 6-TD seismometer in two test sites; (a) first test site is close to the location of point 5 and (b) second test site is close to the location of point 3.

systematic decrease of the fundamental period from south to north, from $1.3 \mathrm{~s}$ in the southern part to about $0.32 \mathrm{~s}$ in the north.

Fundamental period distribution is closely related to bedrock elevations in the area. According to the ground water soundings previously drilled in the area, the depth of bedrock increases progressively in NNE-SSW direction (figure 8). Four crosssections are considered to evaluate the variation of fundamental period in the area. The cross-sections are named as $X-X^{\prime}, Y-Y^{\prime}, Z-Z^{\prime}$ and $Y-Y^{\prime \prime}$ (figure 5). These cross-sections are drawn in figure 11 choosing some representative points satisfying the following criteria: (a) if there is a closely spaced group of microtremor points, the point having a value closest to the average fundamental period is chosen; (b) location of the point should be the closest to the line of cross-section.

Figure 11 shows the variation in the predominant period along each cross-section, where the abscissa represents the distances between the crosssections and the ordinate represents the predominant period obtained from the $H / V$ spectral ratio technique for the respective measurement points. $X-X^{\prime}$ cross-section is in NNW-SSE direction and shows gradual increase of fundamental period up to a value of $2.0 \mathrm{~s}$. The variation in the predominant period is in good correlation with the thickness of the delta: the higher period representing the thicker part of the delta sediments. The $Y$ $Y^{\prime}$ cross-section is in NNE-SSW direction. The fundamental period of first three points in $Y-Y^{\prime}$ cross-section belong to the basements of Yamanlar Mountain and rest of the points support the increase in sediment thickness in the area. The $Z$ $Z^{\prime}$ cross-section is in $\mathrm{E}-\mathrm{W}$ direction and shows variation from shallow basement depth to thick sediments in the western part. $Y-Y^{\prime \prime}$ is $\mathrm{N}-\mathrm{S}$-oriented and shows increase in period from Yamanlar Mountain basements to the coast line implying the increase in sediment thickness, but this time it is seen that the sediment thickness is shallower than the northwestern part of the area represented by $X-X^{\prime}, Y-Y^{\prime}$ and $Z-Z^{\prime}$ cross-sections.

The contour map of fundamental period is shown in figure 12. Fundamental period decreases towards 


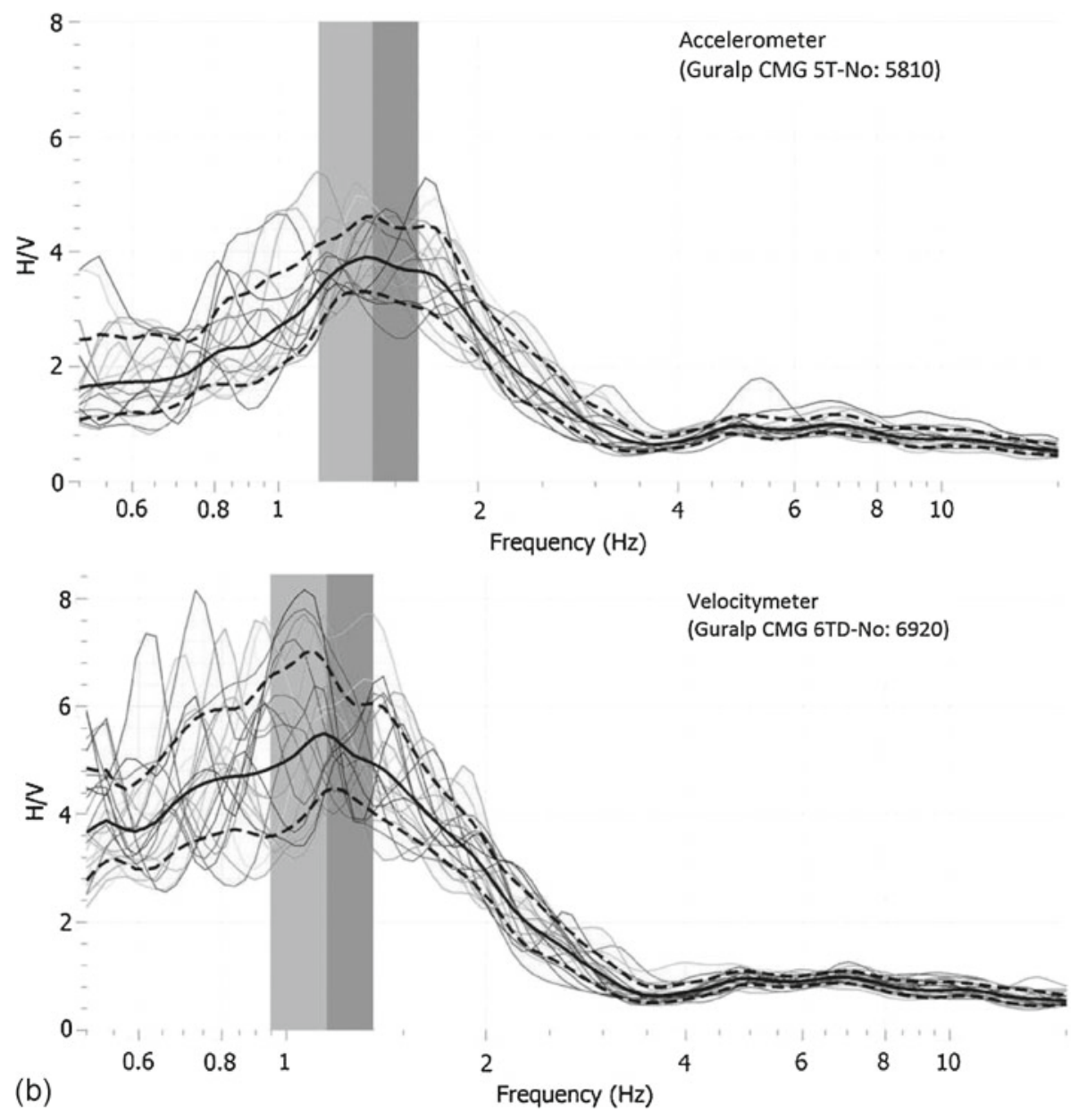

Figure 7. (Continued)

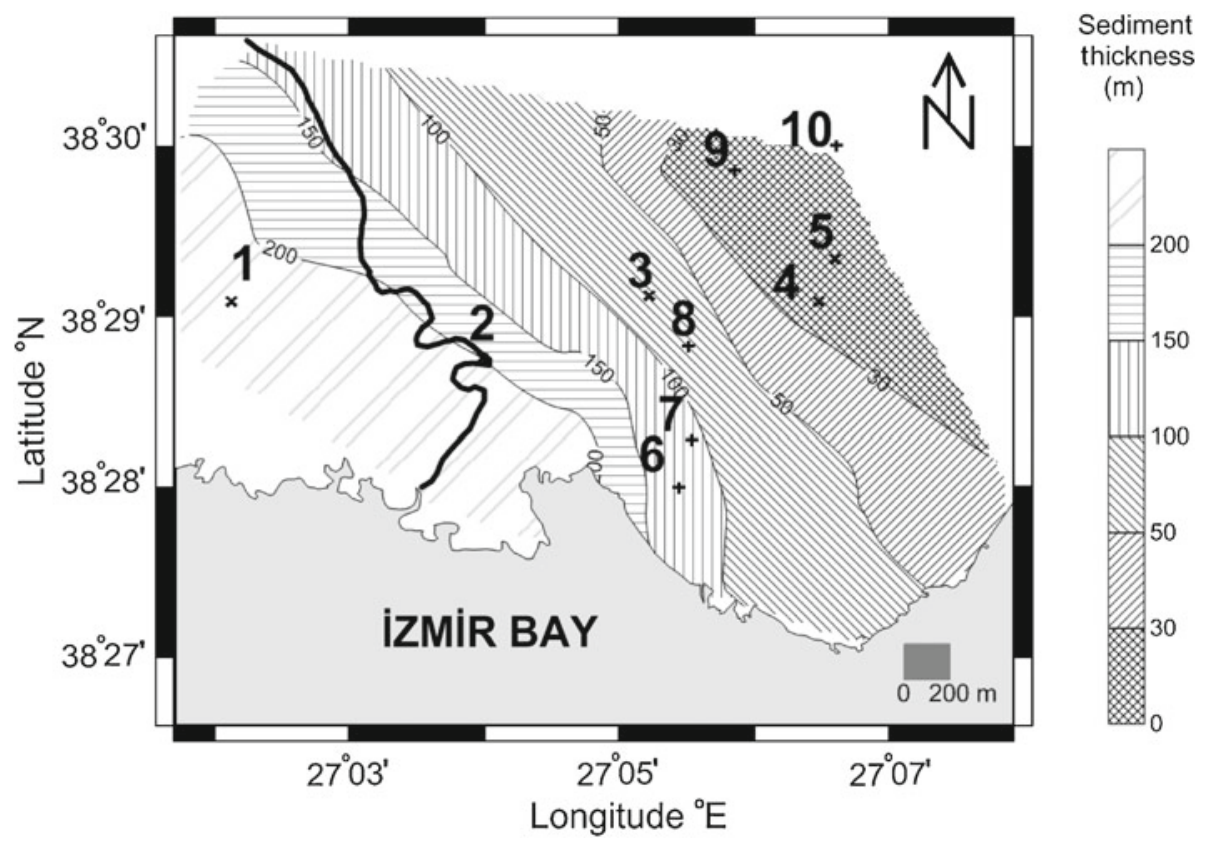

Figure 8. Variation of bedrock depth in the northern coast of İzmir Bay and five site-specific microtremor points from east to west related to figure 9 (cross signs) and five site-specific microtremor points from north to south related to figure 10 (plus signs). 

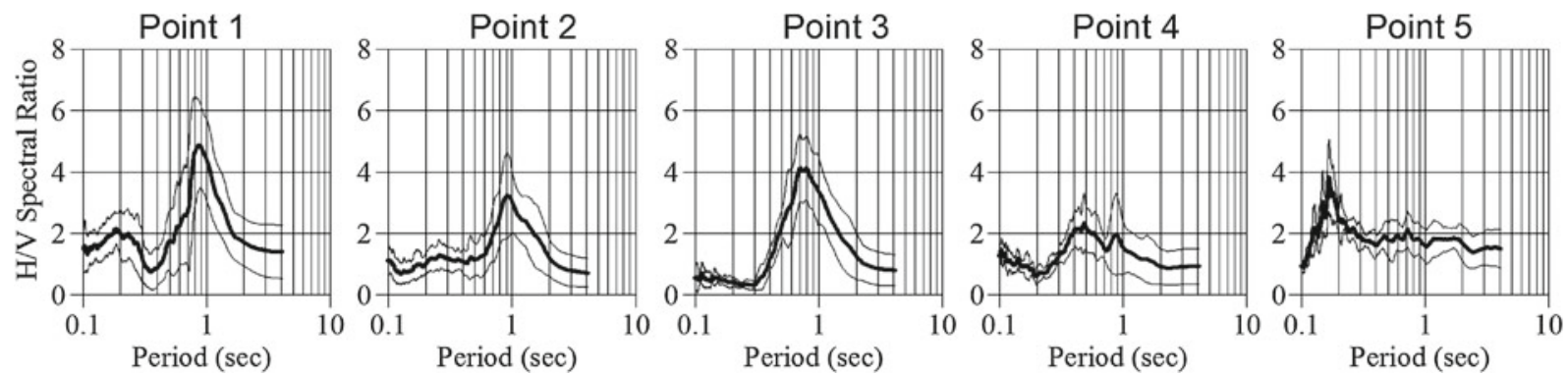

Figure 9. Spectral ratios measured at five stations towards from east to west (locations are denoted by cross signs in figure 8).
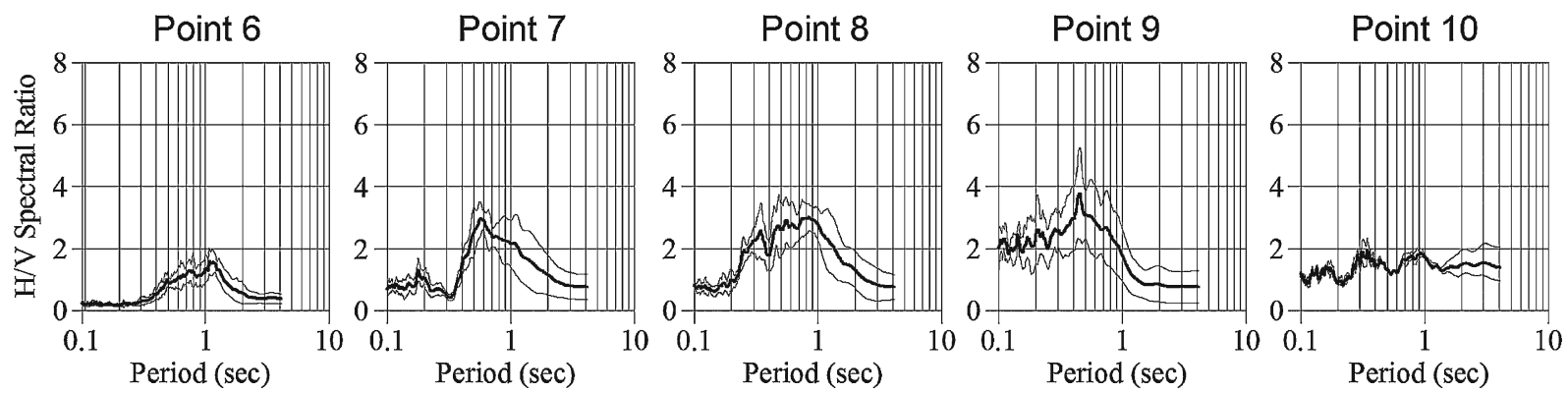

Figure 10. Spectral ratios measured at five stations from north to south (locations are denoted by plus signs in figure 8).
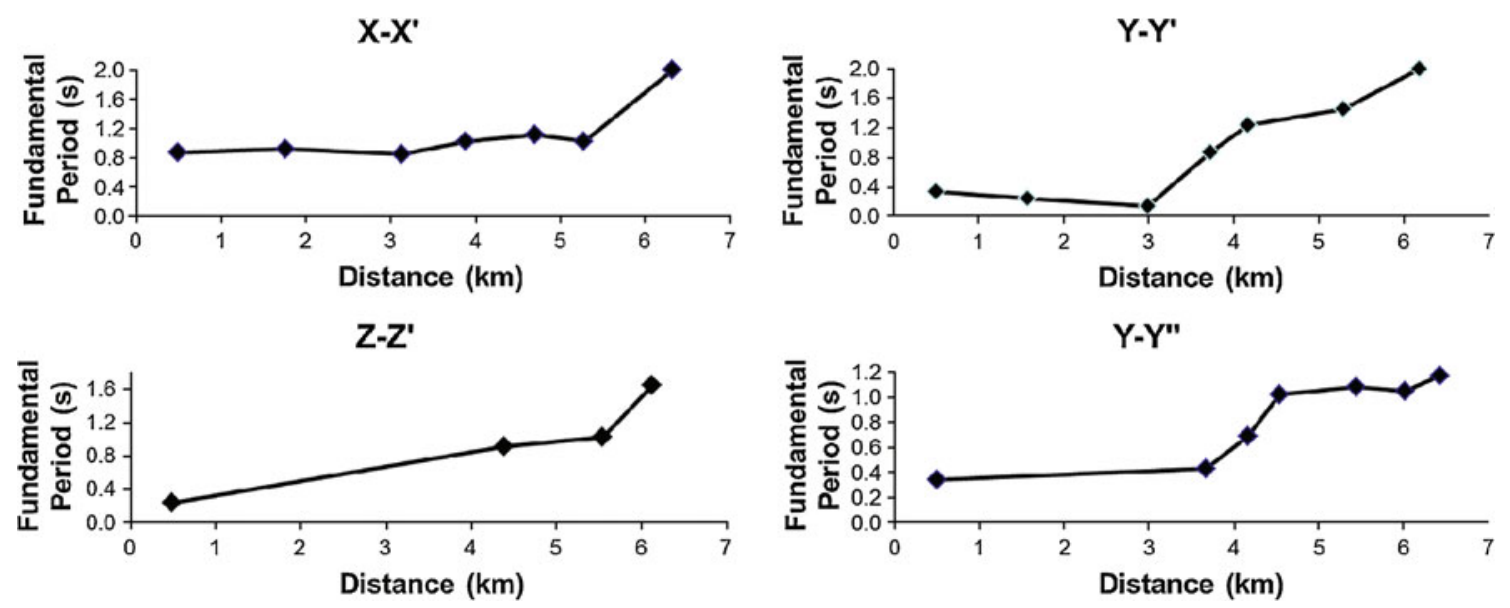

Figure 11. Four cross-sections $X-X^{\prime}, Y-Y^{\prime}, Z-Z^{\prime}$ and $Y-Y^{\prime \prime}$, indicating the fundamental periods in accordance with the sediment thickness in the northern coast of İzmir Bay.

the mountain and has the lowest value where the bedrock outcrop is visible. The fundamental period varies from 0.12 to $2.0 \mathrm{~s}$ in the northern coast of Izmir Bay. About $58 \%$ of the area has a period between 0.82 and $1.28 \mathrm{~s}$ with an average value of $1.08 \mathrm{~s}$.

Detailed borehole information around the location of microtremor measurements provides further analysis of exhibiting a relation between the sediment thickness and fundamental period in an area. For this purpose, 25 boreholes, which are close to the microtremor measurement points and containing a continuous blow count $(N$-value) record of standard penetration tests, are gathered. Among them, 11 boreholes with average shear wave velocity were available (figure 13). These boreholes were drilled for geotechnical and geological investigations in the past by geotechnical companies. Fundamental periods from the velocity structures beneath 11 of borehole locations are calculated by the equation $T=4 H / V_{\mathrm{s}}$ and compared with the fundamental periods obtained by microtremor measurements (table 2). As seen from table 2, there is an agreement between measured and calculated fundamental periods. The highest fundamental periods are calculated in b6, b7, b8 and b11 


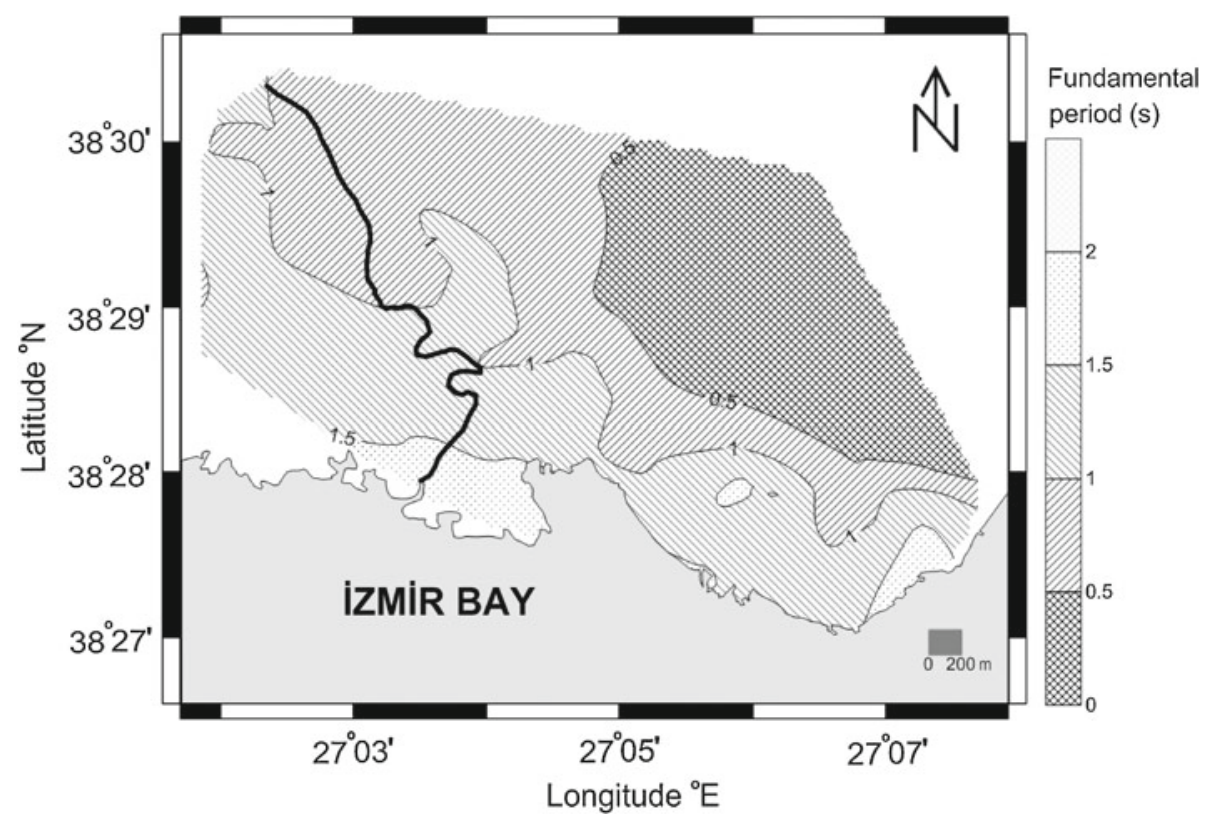

Figure 12. Variation of the fundamental periods of soils in the northern coast of İzmir Bay with $0.5 \mathrm{~s}$ contour interval.

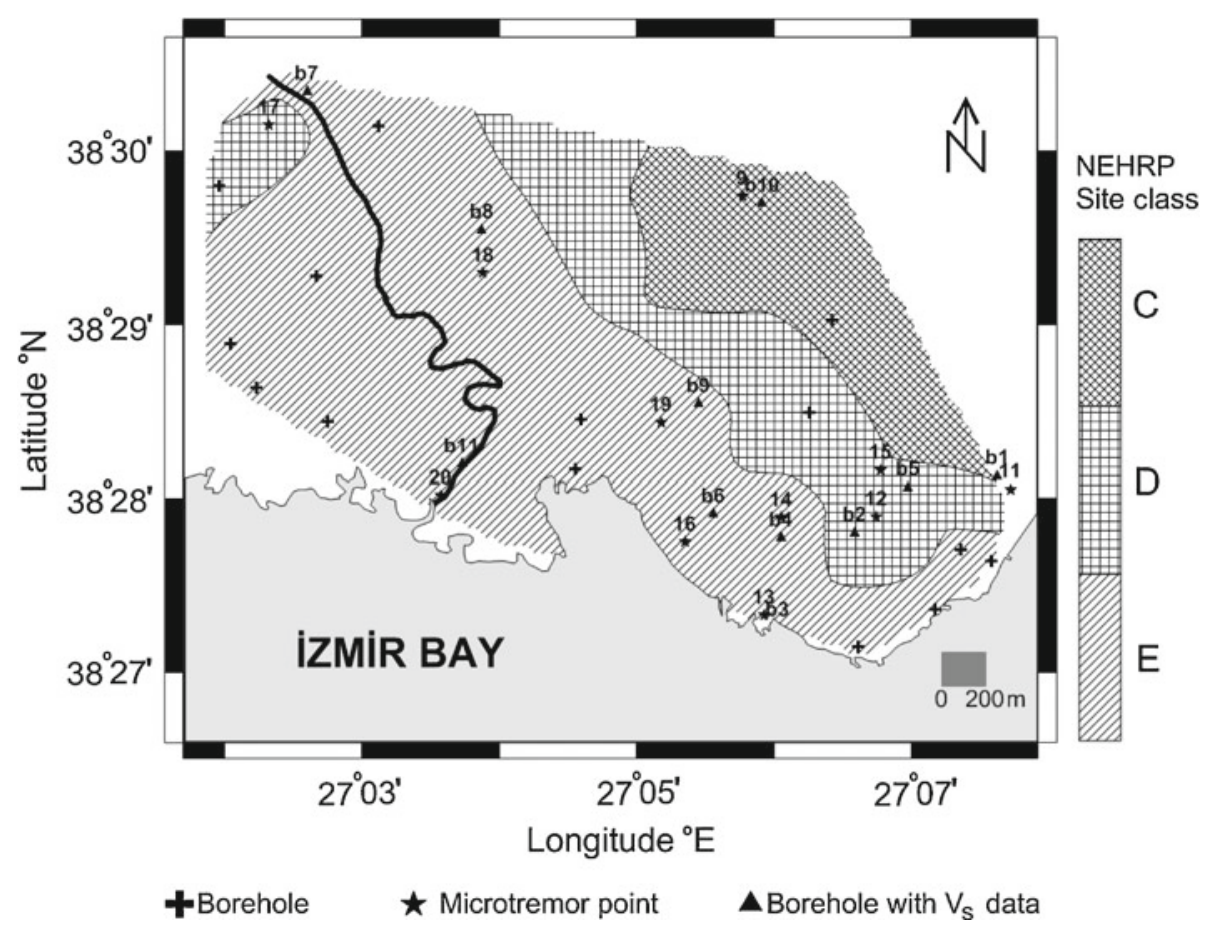

Figure 13. Site classes determined by using SPT- $N$ values for the upper $30 \mathrm{~m}$ of the soil in the study area (NEHRP 2003). Plus signs indicate borehole locations, bold filled triangles show borehole locations with shear wave velocity data, and bold filled stars denote microtremor points.

boreholes, where sediment thickness is more than $100 \mathrm{~m}$.

The study area is categorized into different soil classes using SPT- $N$ values for the upper $30 \mathrm{~m}$ of the soil to find out the relationship between local soil class and predominant period. The classification is performed according to NEHRP (2003) provisions. The value of SPT- $N$ is divided into three ranges $(N<15,15<N<50, N>50)$. There are three main zones in the northern coast of İzmir Bay, namely, Site Classes C, D and E changing in southwestern direction (figure 13). Presence of $\mathrm{D}$ and $\mathrm{E}$ classes of soils is a good indication of soft and loose sediments in the upper $30 \mathrm{~m}$. In 
Table 2. Comparison of fundamental periods.

\begin{tabular}{lcccc}
\hline $\begin{array}{l}\text { Borehole } \\
\text { no. }\end{array}$ & $\begin{array}{c}V_{\text {s average }} \\
(\mathrm{m} / \mathrm{s})\end{array}$ & $\begin{array}{r}\text { Fundamental } \\
\text { period }(\mathrm{s})\end{array}$ & $\begin{array}{c}\text { Microtremor } \\
\text { point }\end{array}$ & $\begin{array}{c}\text { Fundamental } \\
\text { period (s) }\end{array}$ \\
\hline b1 & 244.3 & 0.36 & 11 & 0.26 \\
b2 & 286.2 & 0.64 & 12 & 0.69 \\
b3 & 336.1 & 0.98 & 13 & 0.98 \\
b4 & 349.7 & 0.85 & 14 & 0.95 \\
b5 & 391.4 & 0.39 & 15 & 0.43 \\
b6 & 364.9 & 1.10 & 16 & 1.20 \\
b7 & 356.2 & 1.10 & 17 & 1.02 \\
b8 & 372.7 & 1.20 & 18 & 1.20 \\
b9 & 320.0 & 0.67 & 19 & 0.67 \\
b10 & 295.9 & 0.27 & 9 & 0.24 \\
b11 & 439.5 & 1.97 & 20 & 2.00 \\
\hline
\end{tabular}

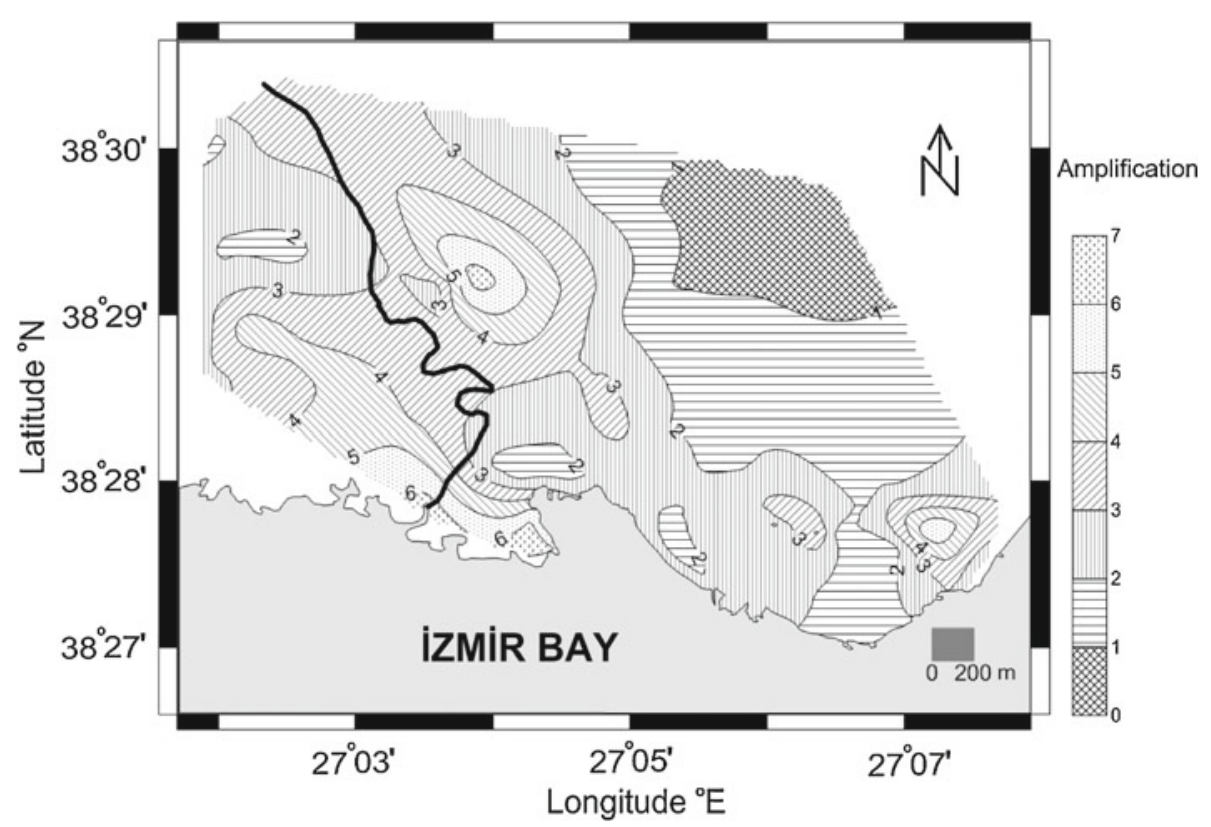

Figure 14. Spatial distribution of amplifications derived at predominant periods by using $H / V$ spectral ratio method.

figure 13, attention should be given to E class soils which also have predominant periods higher than $0.82 \mathrm{~s}$ in the area.

It is probable that when thick loose sediments in the area meet with moderate-strong ground motions, high level of amplification may take place. Although amplification is a concern for the study area, it is kept in mind that there is discussion about quantifying site amplification from $H / V$ spectral ratios (Bard 1998; Gosar and Roser 2010; Mahajan et al. 2011b). As $H / V$ spectral ratios may not provide the actual bandwidth over which the ground motion is amplified, they may underestimate the actual amplification. An example map is prepared only to have a rough idea about variation of amplification at predominant periods (figure 14). It is generally shown that higher amplification values are obtained in the delta composed of sedimentary soils where bedrock exists in deep levels.

\section{Conclusions}

The city of İzmir is in a seismically active zone of Western Anatolia. A moderate-strong earthquake might cause greater harm to the northern part than the other parts of the city due to crowded population and high-speed urbanization. Furthermore, this urbanization takes place on thick, soft sediments, which could amplify the earthquake ground motion to a considerable level. This is a preliminary study to point out the importance of local site effects that could occur in the area due to a probable earthquake motion. 
The findings could be summarized as follows.

- Achievement of fundamental periods with the help of $H / V$ spectral ratios from microtremor measurements supplied useful information for evaluating the sedimentary soils of the northern coast of İzmir Bay.

- The fundamental period of the Quaternary soils are found varying between 0.50 and $2.0 \mathrm{~s}$. The results are consistent with the basin topography; where the sediment thickness increases, the fundamental periods have higher values and vice versa. Buildings with $7-15$ storeys that are located in the area may be vulnerable to a possible earthquake due to the fundamental periods of alluvial deposits in the area.

- The fundamental period of the volcanic rocks andesites are found varying between 0.15 and $0.35 \mathrm{~s}$. Variations in the parameter are considered to be owing to the changes in the quality of rock due to weathering and cracking. The Old Gediz River Delta consists of sediments which are loose/very loose and soft/very soft; hence, the periods are higher in and around the delta up to1.8-2.0 s.

- SPT- $N$ values belonging to 25 boreholes are used to evaluate the local soil conditions by NEHRP provisions. There are three main zones in the northern coast of Izmir Bay (C, D and E sites), based on the NEHRP site classification. Even though, this classification is an indication of soil conditions in the upper $30 \mathrm{~m}$, it can be concluded that site classes are in accordance with the variation of fundamental period in the area.

- As conclusion, higher fundamental periods obtained from the plots of $H / V$ spectral ratios represent thick sediment existence in agreement with the data of deep water soundings in the area. It is well-known that the resonance between the building and ground motion can cause damage. This effect was observed in an area with 7-10 storey buildings, which was $10 \mathrm{~km}$ away from the northern coast during the 2003 Urla earthquake $\left(M_{w}=5.6\right)$ as a long distance effect. In the occurrence of a moderatestrong earthquake, a similar scenario could be expected for the building stock in the northern coast.

\section{Acknowledgements}

The authors are thankful to Prof. Necdet Türk, for the availability of CMG-5T accelerometer during the measurements. Special thanks are due to Prof. Dr M Yalçın Koca, for his contributions on geological information.

\section{References}

Akıncı A, Eyidoğan H, Göktürkler G, Akyol N and Ankaya O 2000 Investigation of the seismic activity and seismic hazard of Izmir city and its vicinity; In: Seismicity of Western Anatolia (BADSEM), (İzmir: Dokuz Eylul Univ. Press, in Turkish), pp. 231-238.

Bard P Y 1998 Microtremor measurements: A tool for site effects estimations? Proc. Second Int. Symp. Eff. Surf. Geol. Seismic Motion, Yokohama, Japan, 3, 1251-1279.

Beroya M A A, Aydin A, Tiglao R and Lasala M 2009 Use of microtremor in liquefaction hazard mapping; Eng. Geol. 107(3-4) 140-153.

Bonnefoy-Claudet S, Leyton F, Baize S, Berge-Thierry C, Bonilla L F and Campos J 2008 Potentiality of microtremor to evaluate site effects at shallow depths in the deep basin of Santiago De Chile; Proc. 14 th WCEE, Beijing, China, http://www.iitk.ac.in/nicee/wcee/ fourteenth_conf_china/.

Bour M, Fouissac D, Dominique P and Martin C 1998 On the use of microtremor recordings in seismic microzonation; J. Soil Dyn. Earthq. Eng. 17 465-474.

Bozkurt E 2001 Neotectonics of Turkey - a synthesis; Geodin. Acta 14 3-30.

Bozkurt E and Sözbilir H 2004 Tectonic evolution of the Gediz Graben: Field evidence for an episodic, two-stage extension in western Turkey; Geol. Mag. 141(1) 63-79.

Chávez-García F J and Cuenca J 1996 Site effects in Mexico city urban zone, A complementary study; J. Soil Dyn. Earthq. Eng. 15 141-146.

Chávez-García F J and Tejeda-Jácome J 2010 Site response in Tecoman, Colima, Mexico - II Determination of subsoil structure and comparison with observations; J. Soil Dyn. Earthq. Eng. 30(8) 717-723.

DEMP-ED 2012 Disaster and Emergency Management Presidency - Earthquake Department, Republic of Turkey Prime Ministry, Ankara, http://www.deprem.gov.tr

Emre Ö, Özalp S, Doğan A, Özaksoy V, Yıldırım C and Göktaş F 2005 Active faults in the vicinity of İzmir and their earthquake potentials; Report No: 10754, Geological Studies Department, General Directorate of Mineral Research and Exploration, Ankara, Turkey (in Turkish).

Emre Ö and Barka A 2000 Active faults between Gediz Graben and Aegean Sea (İzmir Region); In: Seismicity of Western Anatolia (BADSEM), (İzmir: Dokuz Eylul Univ. Press, in Turkish), pp. 131-132.

Erdik M, Biro Y, Onur T, Sesetyan K and Birgoren G 1999 Assessment of earthquake hazard in Turkey and neighboring regions; Ann. Geofis. 42 1125-1138.

Erdoğan B 1990 Tectonic relation of İzmir-Ankara Zone and Karaburun Belt; J. MTA 110 1-16 (in Turkish).

Eskişar T 2008 Determination of soil properties and geotechnical problems of the northern coast of $\dot{I}_{z m i r}$ Bay; $\mathrm{PhD}$ Thesis, Ege University, İzmir, Turkey (in Turkish).

Gamal M A 2009 Using microtremors for microseismic zonation in Cairo's crowded, urban areas; J. Seismol. 13 13-30.

Gosar A 2007 Microtremor HVSR study for assessing site effects in the Bovec basin (NW Slovenia) related to 1998 $M_{w} 5.6$ and $2004 M_{w} 5.2$ earthquakes; Eng. Geol. 91 $178-193$.

Gosar A and Roser J 2010 Microtremor study of site effects and soil-structure resonance in the city of Ljubljana (central Slovenia); Bull. Earthq. Eng. 8 571-592.

Jensen V H 2000 Seismic microzonation in Australia; J. Asian Earth Sci. 18 3-15.

Hasancebi N and Ulusay R 2006 Evaluation of site amplification and site period using different methods for an 
earthquake-prone settlement in Western Turkey; Eng. Geol. 87 85-104.

Koca M Y and Kincal C 2004 Abandoned stone quarries in and around the İzmir city center and their geoenvironmental impacts - Turkey; Eng. Geol. 75 4967.

Kuruoğlu M 2004 Geographical Information System (GIS) based database development and evaluation study for soils of the northern coast of Izmir Bay; PhD Thesis, Dokuz Eylül University, İzmir, Turkey.

Lermo J and Chávez-García F J 1993 Site effect evaluation using spectral ratios with only one station; Bull. Seismol. Soc. Am. 83(5) 1574-1594.

Lermo J and Chávez-García F J 1994 Are microtremors useful in site response evaluation? Bull. Seismol. Soc. Am. 84(5) 1350-1364.

Mahajan A K, Galiana-Merino J J, Lindholm C, Arora B R, Mundepi A K, Rai N and Chauhan N 2011a Characterization of the sedimentary cover at the Himalayan foothills using active and passive seismic techniques; $J$. Appl. Geophys. 73(3) 196-206.

Mahajan A K, Mundepi A K, Chauhan N, Jasrotia A S, Rai N and Gachhayat T K 2011b Active seismic and passive microtremor HVSR for assessing site effects in Jammu city, NW Himalaya, India - A case study; J. Appl. Geophys. 77 51-62.

Magri L, Mucciarelli M and Albarello D 1994 Estimates of site seismicity rates using ill-defined macroseismic data; Pure Appl. Geophys. 143(4) 617-632.

Manakou M V, Raptakis D G, Chávez-García F J, Apostolidis P I and Pitilakis K D 2010 3D soil structure of the Mygdonian basin for site response analysis; J. Soil Dyn. Earthq. Eng. 30(11) 1198-1211.

Mucciarelli M 1998 Reliability and applicability of Nakamura's technique using microtremors: An experimental approach; J. Earthq. Eng. 2 625-638.

Mukhopadhyay S and Bormann P 2004 Low cost seismic microzonation using microtremor data: An example from Delhi, India; J. Asian Earth Sci. 24(3) 271-280.

Nakamura Y 1989 A method for dynamic characteristics estimation of subsurface using microtremor on the ground surface; Quart. Rep. Railway Tech. Res. Inst. 30(1) $25-33$.

NEHRP 2003 Recommended provisions for seismic regulations for new buildings, FEMA 450.

Nguyen F, Van Rompaey G, Teerlynck H, Van Camp M, Jongmans D and Camelbeeck T 2004 Use of microtremor measurement for assessing site effects in Northern Belgium - interpretation of the observed intensity during the Ms = 5.0 June 111938 earthquake; J. Seismol. 8(1) $41-56$.

Nunziata C 2007 A physically sound way of using noise measurements in seismic microzonation, applied to the urban area of Napoli; Eng. Geol. 93 17-30.

RADIUS 1999 Earthquake scenario and earthquake master plan for the city of İzmir (ed.) Erdik M, Boğaziçi University, Istanbul (in Turkish), http://www.izmir.bel. tr/izmirdeprem/izmir.rapor.htm

Rosa-Cintas S, Galiana-Merino J J, Molina-Palacios S, RosaHerranz J, García-Fernández M and Jiménez M J 2011 Soil characterization in urban areas of the Bajo Segura Basin (Southeast Spain) using $H / V, \mathrm{~F}-\mathrm{K}$ and ESAC methods; J. Appl. Geophys. 75(3) 543-557.

Sgarlato G, Lombardo G and Rigano R 2011 Evaluation of seismic site response nearby underground cavities using earthquake and ambient noise recordings: A case study in Catania area, Italy; Eng. Geol. 122(3-4) 281-291.

Tarcan G and Koca Y 2001 Hydrogeological and geotechnical assessments of the Kadifekale landslide area, İzmir, Turkey; Environ. Geol. 40(3) 289-299.

Taymaz T 1997 Active tectonics of the Aegean Sea and surrounding regions: Fault plane mechanism solutions of destructive earthquakes; TÜBİTAK Research Project, Project No: YDABÇAG-438/G, Istanbul.

Teves-Costa P, Matias L and Bard P Y 1996 Seismic behavior estimation of thin alluvium layers using microtremor recordings; J. Soil Dyn. Earthq. Eng. 15 201-209.

Walling M Y, Mohanty W K, Nath S K, Mitra S and John A 2009 Microtremor survey in Talchir, India to ascertain its basin characteristics in terms of predominant frequency by Nakamura's ratio technique; Eng. Geol. 106(3-4) 123-132. 